Errol Prens • Klazina 't Hooft-Benne $\cdot$ Bhupendra Tank Jozef Van Damme · Theodoor van Joost • Robbert Benner

\title{
Adhesion molecules and IL-1 costimulate T lymphocytes in the autologous MECLR in psoriasis
}

Received: 22 September 1994

\begin{abstract}
Membrane molecules such as CD36 (OKM5), intercellular adhesion molecule-1 (ICAM-1, CD54), gamma interferon-induced protein $10(\gamma$-IP10) and IL1 are induced and/or upregulated in psoriatic epidermis. These molecules have important accessory, trafficking or signalling functions in the immune system and also play a role in the pathophysiology of psoriasis. The relevance of adhesion molecules, CD36 and epidermal IL-1 in psoriasis was studied in vitro in the autologous mixed epidermal cell $-\mathrm{T}$ lymphocyte reaction (MECLR). Their level of expression was quantitated in epidermal cell suspensions (ECS) from patients with psoriasis and their function was assessed by blocking with specific $\mathrm{mAbs}$ and antisera or by depleting $\mathrm{CD36}^{+}$ cells from the ECS prior to the MECLR. ECS from psoriatic lesions contained increased numbers of $\mathrm{CD}^{+} 6^{+}$ $(23 \pm 12 \%), \mathrm{ICAM}^{+}(31 \pm 14 \%)$ and $\mathrm{IL}^{+} \mathbf{1}^{+}(57 \pm 21 \%)$ cells. The autologous MECLR was inhibited in samples from all patients by mAb to CD2 (LFA-2), CD11a (LFA-1 $\alpha$ ), CD18 (LFA-1 $\beta$ ), ICAM-1, CD58 (LFA-3) and

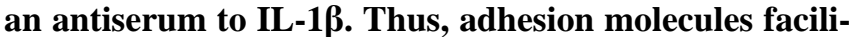
tate inflammation in psoriasis not only via adhesion and recruitment of $T$ lymphocyte in psoriatic lesions, but also via activation of $T$ cells. Furthermore CD36 molecules on psoriatic epidermal cells do not costimulate autologous $T$ lymphocytes in psoriasis. The observed costimulatory function of IL-1 $\beta$ in the MECLR emphasizes its relevance in psoriasis.
\end{abstract}

Key words Adhesion molecules $\cdot$ IL-1 - T cells · Autologous MECLR · Psoriasis

E. P. Prens $(\triangle) \cdot$ K. 't Hooft-Benne $\cdot$ R. Benner

Department of Immunology, Erasmus University Rotterdam,

P.O.Box 1738, 3000 DR Rotterdam, The Netherlands

B. Tank · T. van Joost

Department of Dermatology, Erasmus University Rotterdam and University Hospital Rotterdam-Dijkzigt,

Rotterdam, The Netherlands

J. Van Damme

The Rega Institute, University of Leuven, Leuven, Belgium

\section{Introduction}

The autologous mixed epidermal cell-T lymphocyte reaction (MECLR) is elevated in psoriasis patients [21]. This is mainly due to the spontaneous stimulation of autologous $\mathrm{T}$ lymphocytes by HLA-DR ${ }^{+} / \mathrm{CD}^{2} \mathrm{a}^{-}$epidermal antigen-presenting cells (APC) in the absence of exogenously added antigen [19]. Cytokines produced by activated $\mathrm{T}$ lymphocytes may induce the 'psoriatic phenotype' and upregulate the expression of gamma interferon-induced protein 10 ( $\gamma$-IP10), HLA-DR, ICAM-1 (CD54) and CD36 (OKM5, thrombospondin receptor) on keratinocytes $[1,15]$. Epidermal cells (EC) from psoriatic lesions do indeed express increased levels of CD36, ICAM-1 and $\gamma$-IP10 [2, 3, 10, 11].

In psoriatic lesions, CD36 is intensely expressed on keratinocytes, sporadically on intraepidermal dendritic cells and consistently on dermal dendritic and endothelial cells [3]. Peripheral blood CD $36^{+} / \mathrm{CD} 11 \mathrm{~b}^{-}$monocytes are potent stimulators of autologous $\mathrm{T}$ lymphocytes in the autologous mixed lymphocyte reaction (MLR) [22]. Epidermal $\mathrm{CD}^{2} 6^{+} / \mathrm{CD} 11 \mathrm{~b}^{-}$APC have also been shown to be efficient stimulators of autologous $\mathrm{T}$ lymphocytes [1]. However, the proportion of such APC is low and is increased in healthy human skin only after irradiation with 3 to 5 MED UVB [1]. Based on the crucial role of $\mathrm{CD}^{3} 6^{+}$ APC in the MLR, it is considered possbile that CD36 ${ }^{+} \mathrm{EC}$ from psoriatic lesions could serve as accessory cells in the autologous MECLR [1, 6, 26].

The integrins CD11a (LFA-1 $\alpha$ ), CD18 (LFA-1 $\beta$ ) and their ligands have been shown to be crucial for successful (allo)antigen and mitogen-induced T-cell activation and proliferation [13]. Costimulation via adhesion molecules on epidermal APC is essential for effective antigen-specific T-cell proliferation [16, 20]. The LFA-1/ICAM-1 adhesion pathway may be involved in the pathogenesis of psoriasis by facilitating lymphocyte adhesion, trafficking, activation and stimulation [15]. The expression of IL-1 is abnormal in psoriatic lesions [8, 18]. IL-1 is known to costimulate $\mathrm{T}$ lymphocytes during antigen presentation 
[14]. In the study reported here, the expression of the above-mentioned molecules was quantified and their function in psoriasis was investigated.

\section{Materials and methods}

\section{Patients and controls}

Patients with stable untreated, plaque-type psoriasis underwen shave biopsies and venipuncture after informed consent had been obtained. The autologous MLR and the MECLR were performed with samples from all patients. The number of patients samples of which were tested in each experiment is shown in Tables 2 and 3 and Figs. 1 and 2. EC and peripheral blood mononuclear cells (PBMC) were immunophenotyped. EC isolated from uninvolved skin of nickel dermatitis patients and from patients undergoing abdominal or breast plastic surgery served as controls. Isolated PBMC from these patients and other healthy individuals served also as controls.

\section{Preparation of epidermal cell suspensions}

Split-skin specimens from involved skin of psoriasis patients and from excised skin of controls were obtained using a dermatome. In nickel dermatitis patients, blister roofs were obtained using the suction blister technique [20]. Single cell suspensions of EC were prepared using standard methods [19]. Briefly, split-skin specimens were rinsed with phosphate-buffered saline (PBS), cut into pieces of $\pm 0.5 \mathrm{~cm}^{2}$ and floated in $\mathrm{Ca}^{2+}$ - and $\mathrm{Mg}^{2+}$-free PBS containing $0.0625 \%$ trypsin (ICN, Cleveland, Ohio, USA) and $0.1 \%$ EDTA for $45 \mathrm{~min}$ at $37^{\circ} \mathrm{C}$ in an atmosphere containing $5 \% \mathrm{CO}_{2}$, and in the presence of $0.025 \%$ deoxyribonuclease solution (DNase Sigma, St. Louis, Mo., USA) during the last $15 \mathrm{~min}$ of the incubation. Epidermal sheets were separated from the dermis using fine forceps, cut with scissors and the EC were filtered through sterile $100-\mu \mathrm{m}$ and $30-\mu \mathrm{m}$ mesh nylon gauzes and resuspended in RPMI1640 supplemented with antibiotics, fresh L-glutamine, $20 \mathrm{mM}$ Hepes (RPMI complete medium), 20\% heat-inactivated human AB serum and $0.01 \%$ DNase. Cells were counted using a haemocytometer and their viability was determined by trypan blue exclusion.

\section{Removal of $\mathrm{CD}^{2} 6^{+}$cells from epidermal cell suspensions}

$\mathrm{CD}^{2} 6^{+}$cells were removed from the epidermal cell suspensions (ECS) using anti-CD36 mAb (Table 1) and antimouse Ig-conjugated paramagnetic beads (Dynal, Oslo, Norway) [17]. Briefly, ECS were incubated for $30 \mathrm{~min}$ at $4^{\circ} \mathrm{C}$ with primary $\mathrm{mAb}$, rinsed three times, incubated with the conjugated paramagnetic beads and centrifuged. After $30 \mathrm{~min}$ the pellet was resuspended and the rosettes counted. Rosetted cells were attracted to one side of the tube by a strong magnet and the non-rosetted cells were collected.
The number of rosetted cells was compared with the number of CD $36^{+}$EC before depletion and the efficiency of the depletion was checked again later by immunofluorescent staining. In pilot experiments IgG1 isotype control $\mathrm{mAb}$ was used as the first step followed by the normal immunomagnetic separation procedure.

Isolation of peripheral blood mononuclear cells and purification of $\mathrm{T}$ lymphocytes.

PBMC were isolated using density gradient centrifugation on Lymphoprep (density 1.077; Nyegaard, Oslo, Norway). All rinsing and isolating of other cells was done in RPMI complete medium containing $1 \%$ human AB serum. FCS was not used in this study.

$\mathrm{T}$ lymphocytes were isolated with a rosetting technique using 2-aminoethylisothiouronium bromide (AET)-treated sheep red blood cells. These purified cells consisted of approximately $95 \%$ $\mathrm{CD}^{+}, 99 \% \mathrm{CD} 2(\mathrm{OKT} 11)^{+}, 0-0.5 \% \mathrm{CD}^{+} 4^{+}$and $0-0.5 \% \mathrm{CD} 20^{+}$ cells $[17,18]$. The accessory capacity of this fraction was negligible because this population could not be stimulated by antigen alone $[2,13]$.

Monoclonal antibodies and immunophenotyping of cell suspensions

In addition to the mAbs in Table 1, the following mAbs were used for immunophenotyping: CD3 (Leu-4), CD4 (Leu-3), CD5 (Leu-1), CD8 (Leu-2), CD16 (Leu-11b), CD25 (IL-2 receptor $\alpha$ chain; Becton Dickinson), CD20 (B1; Coulter, Hialeah, Fl., USA), CD11b (CR3, OKM1), CD36 (OKM5; Ortho Diagnostic), CD71 (66IG10; Dr. M. van der Rijn, Amsterdam), CD14 (My4; Dr. J. D. Griffin, Boston, Mass., USA), CD15 (VIM-D5; Dr. W. Knapp, Vienna), CD29 (VLA-B1, 4B4; Coulter), CD45 (HLe-1, FITC-conjugated; Becton Dickinson), CD45RA (2H4; Coulter), IL-1 $\beta$ (Cistron, Pine Brook, N.J., USA) and TcR- $\gamma \delta$ (11F2; Dr. J. Borst, Amsterdam). Immunophenotyping of EC, PBMC or whole blood samples was performed using direct, indirect and double-labelling (SimulSET) immunofluorescence techniques and flow cytometry as described by Van Dongen et al. [28]. CD36/CD45 double-labelling of ECS was carried out by the addition of rhodamine-labelled goat-antimouse IgG to detect the primary OKM5 mAb, and incubation with $10 \%$ normal mouse serum followed by HLe1-FITC mAb. Doublelabelling of PBMC was also performed to detect CD3/CD4, CD3/ CD8, CD3/CD25 and CD3/HLA-DR double-positive cells according to standard procedures (SimulSET). The FACscan data were analysed using the SimulSET and Lysis programs (Becton Dickinson). The results were expressed as the mean percentage \pm SD.

\section{Autologous MECLR and MLR}

Mixed cultures of unpurified EC and PBMC or purified T lymphocytes were set-up in quadruplicate in round-bottomed mi-
Table 1 Source and specificity of antibodies used in depletion and blocking experiments. Mouse IgG1 $(10 \mu \mathrm{g} / \mathrm{ml})$ and $\operatorname{IgG} 2 \mathrm{a}(1 \mu \mathrm{g} / \mathrm{ml})$ isotype control mAbs, and normal goat and normal rabbit sera at a dilution of $1 / 100$ were used as controls

\begin{tabular}{lllll}
\hline mAb & Source & Specificity & Isotype Final \\
concentration
\end{tabular}


crotitre plates (Costar, Cambridge, Mass., USA). To each well, $4 \times$ $10^{4} \mathrm{EC}$ and $1-2 \times 10^{5} \mathrm{PBMC}$ were added to a final volume of 0.2 $\mathrm{ml}$ complete RPMI medium supplemented with $15 \%$ human AB serum. The autologous MLR comprised the spontaneous proliferation of separately plated fractions of PBMC. Only non-irradiated EC were used because we had previously shown that autologous MECLR responses with non-irradiated EC did not differ significantly from those with irradiated EC [19]. The cultures were pulsed with $18.5 \mathrm{kBq}$ tritiated thymidine $\left(\left[{ }^{3} \mathrm{H}\right] \mathrm{TdR}, 185 \mathrm{GBq} / \mathrm{mmol}\right.$ Amersham, UK) on days 6, 7 and 8 and harvested 8 h later onto glass fibre filters. The amount of incorporated $\left[{ }^{3} \mathrm{H}\right] \mathrm{TdR}$ was determined by liquid scintillation counting ( $\beta$-plate; Pharmacia/LKB Uppsala, Sweden). The results were expressed as mean \pm SEM counts per min (cpm) of quadruplicate cultures.

\section{Blocking of the autologous MECLR with antibodies}

The mAbs used in the blocking experiments are shown in Table 1. Sodium azide $\left(\mathrm{NaN}_{3}\right)$ was removed from all $\mathrm{mAbs}$ by overnight dialysis at $4^{\circ} \mathrm{C}$. Anti-HLA-DR mAb was used as a positive control, and a mAb to an irrelevant epitope (anti-CD14, My4) as well as $\mathrm{IgG} 1$ and $\mathrm{IgG} 2 \mathrm{a}$ mouse isotype control mAbs (Becton Dickinson) were used as negative controls in the blocking experiments. The IL-1 antiserum (2580) was raised in a rabbit by immunization with highly purified natural human IL-1 $\beta$. It contained no preservatives and has been shown to neutralize natural and human recombinant IL-1 $\beta$ (Dr. J. Van Damme, Leuven) [27]. At our laboratory this antiserum (dilution 1/16000) completely neutralized $2.5 \mathrm{IU} / \mathrm{ml} \mathrm{rIL-1 \beta}$ in the D10N bioassay. The antiserum to IL- 6 was raised in a goat by immunization with human recombinant IL- 6 and has been shown to neutralize natural and recombinant human IL-6 (Dr. M. Helle and Prof. L. Aarden, CLB, Amsterdam) [12]. This antiserum (dilution 1/16000) completely neutralized 5 IU rIL-6/ml in the B9 bioassay. The EC were preincubated with the antibodies prior to adding PBMC.

Blocking with $\mathrm{mAb}$ of in vitro T-lymphocyte proliferation to control antigens

Pure tetanus toxin (from Clostridium tetani), without preservatives or aluminium hydroxide; Calbiochem, San Diego, Calif., USA) was used at a final concentration of $3 \mu \mathrm{g} / \mathrm{ml}$. Concanavalin A (Con-A) type IV-S (Sigma Chemical Co.) was used at a final concentration of $10 \mu \mathrm{g} / \mathrm{ml}$ in the cultures. Nickel sulphate $\left(\mathrm{NiSO}_{4} \cdot 6 \mathrm{H}_{2} \mathrm{O}\right.$, analytic grade; Merck, Darmstadt) was used at final concentrations of $5,7.5$ and $10 \mu \mathrm{g} / \mathrm{ml}[20]$. The culture and labelling conditions and other procedures were similar to those used in the autologous MECLR.

\section{Statistical analysis}

The results were analysed with STATA (computer program for statistical analysis; CRC, Los Angeles, Calif., USA). The tests used to determine statistical significance were Wilcoxon test (WT) and Wilcoxon's signed rank sum test (WSRT).

\section{Results}

\section{Immunophenotyping of peripheral blood cells}

The absolute number of peripheral blood leucocytes, lymphocytes and monocytes fell within the normal range in all psoriasis patients. The absolute number (mean \pm SD) of activated peripheral blood $\mathrm{T}$ cells was increased in the majority of the patients: $199 \pm 62 \mu \mathrm{CD} 3^{+} / \mathrm{CD}^{2} 5^{+}$cells and $173 \pm 76 \mu \mathrm{l} \mathrm{CD3}{ }^{+} / \mathrm{HLA}^{-\mathrm{DR}^{+}}$cells, as compared with an average of $100 / \mu$ in healthy individuals $(P<0.01$, WT, $n=12)$. The number of TcR $\gamma \delta^{+} \mathrm{T}$ lymphocytes, $\mathrm{CD}^{+} \mathrm{B}$ cells and LFA- $1 \alpha^{+}$, LFA- $1 \beta^{+}$, ICAM- $1^{+}, \mathrm{LFA}^{-} 3^{+}, \mathrm{OKM}^{+}$, $\mathrm{CD}^{2} 6^{+}$and $\mathrm{IL}-1 \beta^{+}$leucocytes did not differ significantly from those of controls.

\section{Immunophenotyping of ECS}

In the ECS of psoriatic lesions, $3.2 \pm 0.5 \%$ (mean \pm SD) CD $45^{+}$cells were observed, but no TcR $\gamma \delta^{+}$cells. In ECS of psoriatic skin, the numbers of $\mathrm{CD} 36^{+}, \mathrm{ICAM}-1^{+}$and IL- $1 \beta^{+}$cells were clearly increased as compared with ECS of uninvolved psoriatic and healthy control skin. Immunofluorescence microscopy showed that ECS of lesional psoriatic skin contained $23 \pm 12 \% \mathrm{CD}^{+} 6^{+}, 31 \pm$ $14 \% \mathrm{ICAM} 1^{+}$and $57 \pm 21 \% \mathrm{IL}-1 \beta^{+}$cells (Table $2 ; P<$ 0.02 , WT, when compared with ECS of normal control skin). In all experiments the proportions of psoriatic EC that were positive for both CD45 and CD36 after double staining were less than $1 \%$. ECS of uninvolved skin from psoriasis patients contained $0-2 \% \mathrm{CD}^{2} 6^{+}$and ICAM-1 ${ }^{+}$ cells, but $12 \pm 3 \%$ IL- $1 \beta^{+}$cells $(P<0.05$, WT, when compared with ECS of normal control skin). ECS control skin contained a mean of $0.5 \pm 0.1 \%$ (range $0-2 \%$ ) CD36 ${ }^{+}$and ICAM- $1^{+}$cells, and $4 \pm 0.5 \%$ IL- $1 \beta^{+}$cells (Table 2 ).

Table 2 CD36 (OKM5) $)^{+}$, CD54 (ICAM-1) ${ }^{+}$and IL-1 $\beta^{+}$EC in lesional, uninvolved psoriatic skin and in healthy control skin. Values are mean percentages \pm SD

\begin{tabular}{|c|c|c|c|}
\hline & $\begin{array}{l}\text { Lesional } \\
\text { psoriatic } \\
\text { skin } \\
(n=15)\end{array}$ & $\begin{array}{l}\text { Uninvolved } \\
\text { psoriatic } \\
\text { skin } \\
(n=8)\end{array}$ & $\begin{array}{l}\text { Healthy } \\
\text { control } \\
\text { skin } \\
(n=10)\end{array}$ \\
\hline $\mathrm{CD}^{3} 6^{+}$ & $23 \pm 12 \%$ & $0.3 \pm 0.1 \%$ & $0.5 \pm 0.1 \%$ \\
\hline ICAM-1+ & $31 \pm 14 \%$ & $0.6 \pm 0.1 \%$ & $0.5 \pm 0.1 \%$ \\
\hline IL- $1 \beta^{+}$ & $57 \pm 21 \%$ & $12 \pm 3 \%$ & $4 \pm 0.5 \%$ \\
\hline
\end{tabular}

Blocking of the autologous MECLR

with $\mathrm{mAb}$ to adhesion molecules

The functional role of adhesion molecules was investigated by adding antibodies to the autologous MECLR. The proliferative responses obtained were compared with the proliferative responses of the 'untreated' MECLR. The results obtained using mAbs specific for the adhesion molecules CD2 (LFA-2/T11), CD11a (LFA-1 $\alpha$ ), CD18 (LFA-1 $\beta$ ), CD54 (ICAM-1) and CD58 (LFA-3) are shown in Fig. 1. These mAbs clearly and consistently inhibited the autologous MECLR $(P<0.0025$, WSRT). The isotype control $\mathrm{mAb}$ had no effect in this in vitro system. The mean $\pm \mathrm{SEM}\left[{ }^{3} \mathrm{H}\right] \mathrm{TdR}$ incorporation expressed as cpm in the autologous MECLR in the presence of $\operatorname{IgG} 1$ and IgG2a control mAbs were $21277 \pm 3095$ and $20831 \pm$ $3217(n=10)$, respectively, which did not differ significantly from the untreated MECLR. 


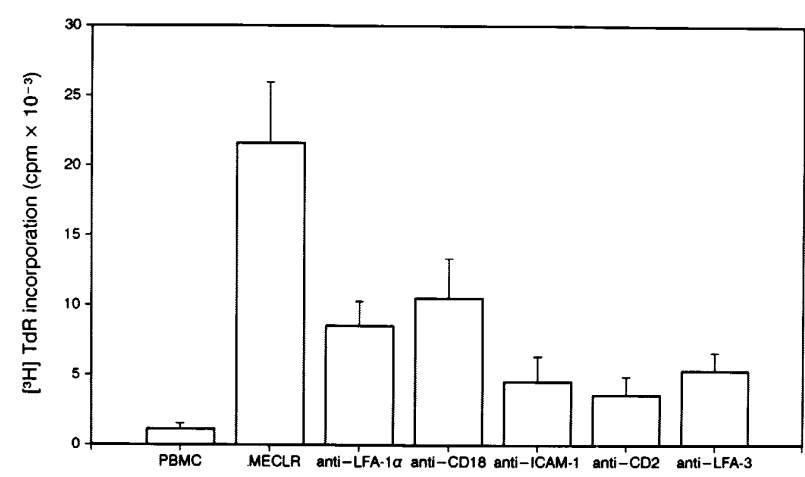

Fig. 1 The effect of blocking with anit-LFA mAb on the autologous MECLR. Each bar represents the mean \pm SEM $\left[{ }^{3} \mathrm{H}\right] \mathrm{TdR}$ incorporated in the autologous MLR, MECLR and blocked MECLR with samples from 12 patients. All mAbs significantly inhibited the autologous MECLR $(P<0.0025$, WSRT). The mean \pm SEM $\left[{ }^{3} \mathrm{H}\right] \mathrm{TdR}$ incorporation in the autologous MECLR in the presence of IgG1 and IgG2a isotype control mAbs was $21277 \pm 3095$ and $20831 \pm 3217(n=10)$, respectively, which did not differ significantly from the values from the untreated MECLR

Blocking of the autologous MECLR with an IL- $1 \beta$-specific antiserum

The IL- $1 \beta$-specific antiserum resulted in a consistent inhibition (mean $35 \pm 14 \%, P<0.002$, WSRT) of the autologous MECLR (Fig. 2). The controls comprised EC preincubated with IgG2a isotype control $\mathrm{mAb}, 1 \%$ normal rabbit serum, a goat IL-6-specific antiserum and anti-HLADR mAb prior to the autologous MECLR. Anit-IL-6 antiserum had no effect on the autologous MECLR, whereas anti-HLA-DR mAb drastically inhibited the reaction $(91 \pm 8 \%, P<0.002$, WSRT; Fig. 2$)$. The mean \pm SEM $\left[{ }^{3} \mathrm{H}\right] \mathrm{TdR}$ incorporation in the autologous MECLR in the presence of $\mathrm{IgG} 2 \mathrm{a}$ isotype control $\mathrm{mAb}$ and $1 \%$ normal

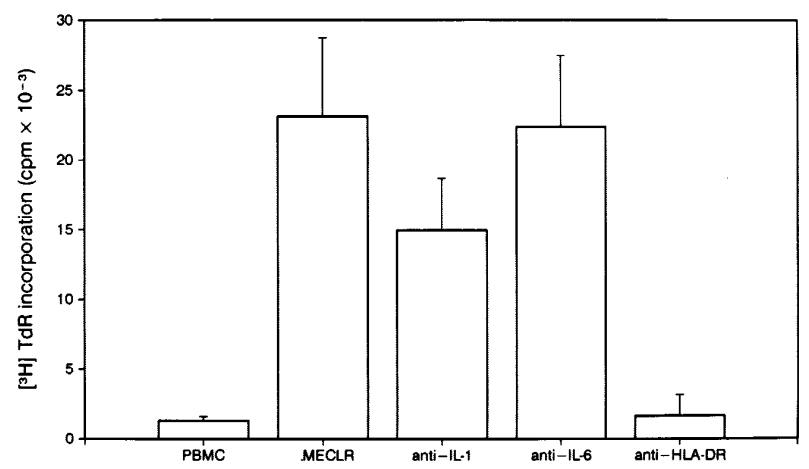

Fig. 2 The effect of blocking with anti-IL-1 $\beta$, anti-IL-6 and antiHLA-DR antibodies on the autologous MECLR. Each bar represents the mean \pm SEM $\left[{ }^{3} \mathrm{H}\right] \mathrm{TdR}$ incorporated in the autologous MLR, MECLR and blocked MECLR with samples from 15 patients. The anti-HLA-DR $\mathrm{mAb}$ and anti-IL-1 $\beta$ polyclonal antiserum significantly inhibited the autologous MECLR $(P<0.002$, WSRT). The mean $\pm \mathrm{SEM}\left[{ }^{3} \mathrm{H}\right] \mathrm{TdR}$ incorporation in the autologous MECLR in the presence of $\operatorname{IgG} 2 \mathrm{a}$ isotype control $\mathrm{mAb}$ and $1 \%$ normal rabbit serum were $20831 \pm 3217$ and $23682 \pm 2644(n=10)$, respectively. These values did not differ significantly from the values from the untreated MECLR rabbit serum were $20831 \pm 3217$ and $23682 \pm 2644(n=$ $10)$, respectively. These values did not differ significantly from the results from the untreated MECLR. When the same antibodies and highly purified AET-SRBC-T lymphocytes from three psoriatic patients were used in the autologous MECLR, identical results were obtained.

Furthermore, as a control, autologous EC preincubated with anti-IL-1 $\beta$ antiserum were used to present nickel to highly purified peripheral blood $\mathrm{T}$ lymphocytes from eight different patients with proven contact dermatitis to nickel. In these experiments the anti-IL-1 $\beta$ antiserum caused varying effects. A mean inhibition of $9 \%$ in three cases and a slight increase in the proliferative response of $16 \%$ in five cases were observed. The results in these cases were in clear contrast to the consistent inhibitory effects obtained in the autologous MECLR with psoriatic samples.

\section{Depletion of $\mathrm{CD}^{2} 6^{+}$cells from psoriatic ECS}

Depletion of $\mathrm{CD}^{2} 6^{+}$cells using an immunomagnetic rosetting technique was reproducible with an almost complete removal of $\mathrm{CD}_{3} 6^{+}$cells from the ECS. After depletion, ECS of psoriatic lesions, contained $0-0.5 \% \mathrm{CD}^{+} 6^{+}$ cells as determined by immunofluorescence microscopy. As shown in Table 3, the removal of $\mathrm{CD}^{2} 6^{+}$cells did not significantly affect the autologous MECLR. In three cases a slight decrease and in six cases varying increases in the proliferative responses were observed. The results of controls using IgG1 mAb are shown in Table 3.

Table 3 The effect of depletion of EC positive for CD36 (OKM5) on the autologous MECLR with samples from psoriatic patients. Values represent the mean \pm SEM $\left[{ }^{3} \mathrm{H}\right] \mathrm{TdR}$ incorporation of quadruplicate cultures. The source and concentration of the anti-CD36 and control mAb used are shown in Table 1 (NT not tested)

\begin{tabular}{lrllll}
\hline \multirow{2}{*}{$\begin{array}{l}\text { Pa- } \\
\text { tient } \\
\text { no. }\end{array}$} & \multicolumn{2}{l}{ Proliferation $(\mathrm{cpm})$} & & & \\
\cline { 5 - 6 } & Non-depleted EC & & \multicolumn{2}{l}{ CD36-depleted EC } \\
\cline { 2 - 3 } \cline { 5 - 6 } & \multicolumn{1}{l}{ PBMC } & MECLR & & MECLR & IgG1 control \\
\hline 1 & $944 \pm 175$ & $24636 \pm 2536$ & & $27351 \pm 1605$ & NT \\
2 & $484 \pm 180$ & $16196 \pm 1628$ & & $19029 \pm 1254$ & $14384 \pm 1945$ \\
3 & $1773 \pm 862$ & $15369 \pm 4759$ & & $21843 \pm 6830$ & $20707 \pm 3208$ \\
4 & $613 \pm 206$ & $20940 \pm 2132$ & & $24911 \pm 2037$ & $18653 \pm 2911$ \\
5 & $1093 \pm 223$ & $16428 \pm 1452$ & & $14052 \pm 1175$ & $19479 \pm 1613$ \\
6 & $951 \pm 317$ & $15324 \pm 1596$ & & $18773 \pm 2567$ & NT \\
7 & $2537 \pm 763$ & $37442 \pm 7059$ & & $39190 \pm 4872$ & $43810 \pm 6459$ \\
8 & $1319 \pm 341$ & $26635 \pm 1755$ & & $24860 \pm 2199$ & NT \\
9 & $1161 \pm 128$ & $15496 \pm 1235$ & & $12864 \pm 1307$ & NT \\
\hline
\end{tabular}

\section{Discussion}

The increased expression of CD36 and ICAM- 1 observed in this study in psoriatic lesions has also been observed in previous studies on psoriasis by others. Increased CD36 
expression has also been described in other inflammatory dermatoses, suggesting upregulation of these molecules by proinflammatory cytokines $[2,3,11]$. The microscopic appearance of $\mathrm{CD} 36^{+} \mathrm{EC}$ in ECS was that of medium to large-sized keratinocytes. The low number of $\mathrm{CD}_{4} 5^{+}$/ $\mathrm{CD}^{2} 6^{+} \mathrm{EC}$ as determined by double-labelling, and their expression in the upper epidermal layers indicate that the majority of the $\mathrm{CD}^{+} 6^{+}$cells in lesional skin are keratinocytes. Although, intense expression of CD36 was observed on a considerable proportion of psoriatic keratinocytes, the results of the depletion experiments suggest that $\mathrm{CD} 6^{+}$keratinocytes do not serve as accessory cells in the autologous MECLR. These results and those of a previous study on the autologous MECLR in psoriasis suggest that keratinocytes do not serve as accessory cells in this system. This may be explained by the fact that a limited number of keratinocytes in psoriatic lesions express MHC class II antigens which seem necessary for such an accessory function [26]. Consistent with this is the profound inhibitory effect of anti-HLA-DR mAb in the autologous MECLR (Fig. 2).

The results of the blocking studies using mAbs to the integrin family of adhesion molecules and their ligand(s) indicate a clear costimulatory role of these molecules in the autologous MECLR in psoriasis. This finding is consistent with the reported costimulatory function of these adhesion molecules in comparable in vitro systems using skin APC [25]. In accordance with the decreased stimulation of $\mathrm{T}$ cells after addition of anti-LFA $\mathrm{mAb}$, in this study a reduced cell-cell aggregation (less clustered cells) was observed in the mixed cultures upon light-microscopic examination. Further illustrations of the importance of adhesion molecules in psoriasis are the LFA-mediated adherence of peripheral blood lymphocytes to cryostat sections of psoriatic lesions and the activation of keratinocytes by this adherence [7, 24]. Taken together, the results of our investigations indicate that in psoriatic patients, LFA-3 and ICAM-1 membrane molecules on HLA-DR ${ }^{+} / \mathrm{CD}_{1} \mathrm{a}^{-}$epidermal APC deliver costimulatory signals to T cells in the autologous MECLR [19]. In the same system, the role of ICAM-1+ keratinocytes seems restricted to co-immobilization of $\mathrm{T}$ lymphocytes resulting in cluster formation, and consequent $\mathrm{T}$ cell activation by epidermal APC. However, under certain in vitro conditions, keratinocytes may serve as accessory cells in T-cellmediated responses $[16,23]$. IFN- $\gamma$-treated cultured keratinocytes serve as accessory cells in an autologous mAb T-cell-mediated response to bacterial superantigen, PHA and immobilized anti-CD3 mAb, but not in an allogeneic T-cell-mediated response [16]. In this type of stimulation of autologous $\mathrm{T}$ cells, costimulatory signals are delivered via the LFA-1/ICAM-1 pair of adhesion molecules. It would be useful to investigate the effects of nominal or autologous antigen in this system to further delineate its in vivo relevance. MHC class I- and class II-independent, LFA-1/ ICAM-1-mediated stimulation of allogeneic and autologous PBMC by PMA-treated cultured keratinocytes, but abrogation of their stimulatory capacity by IFN- $\gamma$ pretreatment, has also been reported [23].
The observed inhibition by the antibody to IL- $1 \beta$ indicates that IL- $1 \beta^{+}$psoriatic EC deliver costimulatory signals to autologous T lymphocytes in the MECLR. The cellular source of the costimulatory IL-1 in the autologous MECLR remains unclear, because both keratinocytes and dendritic epidermal APC are known to produce this cytokine $[4,9]$. Stimulation via peripheral blood monocytederived IL-1 appeared to be negligible in our system because of (1) the consistent, identical results when highly purified $\mathrm{T}$ cells were used and (2) the diverse effects of the same antibody to IL-1 $\beta$ in tetanus toxin and nickelstimulated T cells using EC as APC. The functional relevance of IL-1 has been well documented in several in vitro systems, but its role in chronic inflammatory skin disease is not yet fully understood. Indirect indications of its importance are the findings that dendritic cell-derived IL-1 $\beta$ is an essential molecule required for the initiation of primary immune responses in skin and that skin-derived $\mathrm{IL}-1$ is a potent inflammatory agent in human skin in vivo $[5,9]$. The accessory function of IL- 1 in the autologous MECLR and its elevated expression on EC from uninvolved and lesional skin observed in this study emphasizes the relevance of the reported IL-1 dysregulation in psoriasis [8].

Acknowledgements We thank J. van der Stek, T. M. van Os, Prof. L. Aarden, R. Debets, Dr. R. Rothlein, Prof. T. Springer, Prof. C. Figdor, Dr. S. J. Hopkins and Dr. R. van Lier for their contribution.

\section{References}

1. Baadsgaard O, Fox DA, Cooper KD (1988) Human epidermal cells from ultraviolet light-exposed skin preferentially activate autoreactive $\mathrm{CD}_{4}^{+} 2 \mathrm{H}^{+}$suppressor-inducer lymphocytes and $\mathrm{CD}^{+}$suppressor/cytotoxic lymphocytes. J Immunol 140:17381744

2. Baadsgaard O, Tong P, Elder JT, Hansen ER, Ho V, Hammerberg C, Lange-Vejlsgaard G, Fox DA, Fisher G, Chan LS (1990) UM4D4+ (CDw60) $\mathrm{T}$ cells are compartmentalized into psoriatic skin and release lymphokines that induce a keratinocyte phenotype expressed in psoriatic lesions. J Invest Dermatol 95:275-282

3. Barker JN, Markey AC, Allen MH, MacDonald DM (1989) Keratinocyte expression of OKM5 antigen in inflammatory cutaneous disease. Br J Dermatol 120:613-818

4. Blanton RA, Kupper TS, McDougal JK, Dower S (1986) Regulation of interleukin 1 and its receptor in human keratinocytes. Proc Natl Acad Sci USA 86:1273-1277

5. Camp R, Fincham N, Ross J, Bird C, Gearing A (1991) Potent inflammatory properties in human skin of interleukin-1 alphalike material isolated from normal skin. J Invest Dermatol 96: 294-295

6. Chang EY, Hammerberg C, Fisher G, Baadsgaard O, Ellis CN, Voorhees JJ, Cooper KD (1992) T-cell activation is potentiated by cytokines released by lesional psoriatic, but not normal, epidermis. Arch Dermatol 128: 1479-1486

7. Chin YH, Falanga V, Cai JP (1990) Lymphocyte adhesion to psoriatic dermal endothelium: mechanism and modulation. J Invest Dermatol $95: 29 \mathrm{~S}-31 \mathrm{~S}$

8. Cooper KD, Hammerberg C, Baadsgaard O, Elder JT, Chan LS, Sauder DN, Voorhees JJ, Fisher G (1990) IL-1 activity is reduced in psoriatic skin. Decreased IL-1 alpha and increased nonfunctional IL-1 beta. J Immunol 144:4593-4603 
9. Enk AH, Angeloni VL, Udey MC, Katz SI (1993) An essential role for Langerhans cell-derived IL-1 beta in the initiation of primary immune responses in skin. J Immunol 150:3698-3704

10. Gottlieb AB, Luster AD, Posnett DN, Carter DM (1989) Detection of a gamma interferon-induced protein IP-10 in psoriatic plaques. J Exp Med 168:941-948

11. Griffiths CE, Voorhees JJ, Nickoloff BJ (1989) Characterization of intercellular adhesion molecule-1 and HLA-DR expression in normal and inflamed skin: modulation by recombinant gamma interferon and tumor necrosis factor. J Am Acad Dermatol 20:617-629

12. Helle M, Boeije L, Groot E de, Vos A de, Aarden L (1991) Sensitive ELISA for interleukin-6. Detection of IL-6 in biological fluids: synovial fluids and sera. J Immunol Methods 138 : $47-56$

13. Makgoba MW, Sanders ME, Shaw S (1989) The CD2-LFA-3 and LFA-1-ICAM-1 pathways: relevance to T cell recognition. Immunol Today 10:417-422

14. McKean DJ, Podzorski R, Bell MP, Nilson AE, Huntoon CJ, Slack J, Dower S, Sims J (1993) Murine T helper cell-2 lymphocytes express type I and type II IL-1 receptors, but only the type I receptor mediates costimulatory activity. J Immunol $151: 3500-3510$

15. Nickoloff BJ (1991) The cytokine network in psoriasis. Arch Dermatol 127:871-884

16. Nickoloff BJ, Mitra RS, Green J, Zheng XG, Shimizu Y, Thompson C, Turka LA (1993) Accessory cell function of keratinocytes for superantigens. Dependence on lymphocyte function-associated antigen-1/intercellular adhesion molecule-1 interaction. J Immunol 150:2148-2159

17. Nilsson H, Johansson C, Scheynius A (1987) Removal of Langerhans cells from human epidermal cell suspensions by immunomagnetic particles. J Immunol Methods 105:165-169

18. Prens EP, Benne K, Van Damme J, Bakkus M, Brakel K, Benner R, Joost $T$ van (1990) Interleukin-1 and interleukin-6 in psoriasis. J Invest Dermatol 95 : 121S-124S

19. Prens EP, Benne K, Joost T van, Benner R (1991) The autologous mixed epidermal cell-T lymphocyte reaction is elevated in psoriasis: a crucial role for $\mathrm{HLA}-\mathrm{DR}^{+} / \mathrm{CD}^{-} \mathrm{a}^{-}$antigen presenting cells. J Invest Dermatol 96:880-887
20. Prens EP, Benne K, Joost T van, Benner R (1991) Differential role of lymphocyte function-associated antigens in the activation of nickel-specific peripheral blood T lymphocytes. J Invest Dermatol 97:885-891

21. Schopf RE, Hoffmann A, Jung M, Morsches B, Bork K (1986) Stimulation of $\mathrm{T}$ cells by autologous mononuclear leukocytes and epidermal cells in psoriasis. Arch Dermatol Res 279:89-94

22. Shen HH, Talle MA, Goldstein G, Chess L (1983) Functional subsets of human monocytes defined by monoclonal antibodies: a distinct subset of monocytes contains the cells capable of inducing the autologous mixed lymphocyte culture. J Immunol $130: 698-705$

23. Simon JC, Cruz PJ, Bergstresser PR, Davis LS, Tigelaar RE (1991) Phorbol myristate acetate-activated keratinocytes stimulate proliferation of resting peripheral blood mononuclear lymphocytes via a MHC-independent, but protein kinase C- and intercellular adhesion molecule-1-dependent, mechanism. J Immunol 146:476-484

24. Stoof TJ, Mitra RS, Sarma V, Dixit VM, Nickoloff BJ (1992) Keratinocyte activation following T-lymphocyte binding. J Invest Dermatol 98:92-95

25. Teunissen MBM, Wormmeester J, Rongen HAH, Kapsenberg ML, Bos JD (1991) Conversion of human epidermal Langerhans cells into interdigitating cells in vitro is not associated with functional maturation. Eur J Dermatol 1:45-54

26. Udey MC, Peck RD, Pentland AP, Schreiner GF, Lefkowith JB (1991) Antigen-presenting cells in essential fatty acid-deficient murine epidermis: keratinocytes bearing class II (Ia) antigens may potentiate the accessory cell function of Langerhans cells. J Invest Dermatol 96:950-958

27. Van Damme J, De Ley M, Van Snick J, Dinarello CA, Billiau A (1987) The role of interferon-beta 1 and the $26-\mathrm{kDa}$ protein (interferon beta 2) as mediators of the antiviral effect of interleukin 1 and tumor necrosis factor. J Immunol 139: 1867-1872

28. Van Dongen JJM, Adriaansen HJ, Hooijkaas H (1987) Immunological marker analysis of cells in the various hematopoietic differentiation stages and their malignant counterparts. In: Ruiter DJ, Fleuren J, Warnaar SO (eds) Application of monoclonal antibodies in tumor pathology. M. Nijhoff, Dordrecht, pp 87-116 